\title{
Mechanism of Valence Change in Mandailing Language: Linguistics Typology
}

\author{
Ernita Daulay $^{1}$ \& Mulyadi $^{2}$
}

1,2, Faculty of Cultural Sciences, University of Sumatera Utara, Inddonesia

\begin{tabular}{l}
\hline \hline ARTICLE INFO \\
\hline \hline Article history: \\
Received May 30, 2021 \\
Revised June 30, 2021 \\
Accepted July 1, 2021
\end{tabular}

Keywords:

Valence Change

Linguistic Typology

Mandailing Language

\begin{tabular}{l}
\hline Conflict of Interest: \\
None \\
\hline Funding: \\
None
\end{tabular}
ernitadaulay@students.usu.ac.id

Corresponding Author: Ernita Daulay, Faculty of Cultural Sciences University of Sumatera Utara. E-mail: \begin{abstract}
This paper described the mechanism of valence change in Mandailing language. The concept of valence refers to the number of arguments a verb that serves as a predicate in a clause can present. Changing the valence of verbs in Mandailing through a causative process causes the verbs to experience an increase in valence. This study was included a qualitative descriptive study, in which the method is a study of language typology and the data analyzed based on the problems discussed using the method Agih. The results of the data analysis of this study are presented using an informal method in the form of explanation or exposure using ordinary words or verbal language. The determinants used by this method are the language elements in the Mandailing language. The purpose of this study was to find what types of verbs in the Mandailing language can experience changes in valence, symptoms, and their process of change, and the semantic role of these verbs. The data analysis from this study was obtained through the observation method and the proficient method with informants; based on the results of the analysis, it can be concluded that changes in the valence of the Mandailing language occur mainly in intransitive, transitive, transitive verbs, which are grouped into symptoms that cause valence reduction and valence expansion. This study is also expected to inspire some researchers interested in the mechanism of valence change in Mandailing language, either micro or macro.
\end{abstract}

(C) Ernita Daulay, Mulyadi

This is an open access article under the CC BY-SA 4.0 international license.

\section{Introduction}

Luciens Jesmiere (1959) was a French linguistic scientist who discovered that the use of terminology in which he tried to use the term valence in chemistry and applied it to linguistics was aimed at syntactic relationships describing the existence of a compound of elements or the compounding of clause-building elements or sentences in the language. This explanation is then represented by Verhaar (2012) he asserted the traditional classification of verbs called "transitive" and "intransitive." This classification is the term "valence," i.e., one or so-called intransitive verbs, or which have more than one valence, i.e., two or three are called transitive verbs, these two forms seem to be completely different. Transitive and intransitive terms can be used against verbs with grammatical subjects or objects. Knowing transitive and valence is different, but transitive terms are still needed in the discussion of this valence. The need for transitive terms is due to a relationship concerning the subject and grammatical objects in a clause or sentence. Payne, 1977 in Budiarta (2013) explained that both valence change in ascent and valence reduction are grammatical processes that can bind several arguments to a clause or sentence construction. The valence ascent process is the addition of new arguments to the core structure of the clause, such as ticking and ticking.

Meanwhile, in the process of decreasing valence is a decrease in the number of arguments with the transfer of the core argument into a non-inti argument. The use of verb valence is a morphological study that discusses the categories of words bound to verbs arranged into a sentence. However, not all words or elements of a 
sentence are verb valence (Paul, 1999, p. 132). Kridalaksana (2000, p. 226) explains that valence is the syntactic relationship between verbs and surrounding elements, such as verb transitivity and verb mastery. Greenberg (1963, p. 76-77) suggests that the syntax typologically developed word order on the initial sentence construction of a language can be a measure for predicting several things in grammatical language. There is a wording (word order) that consists of $\mathrm{S}, \mathrm{V}, \mathrm{O}$. This is what makes researchers interested in the study of valence change in Mandailing language because basically, the structure of Mandailing language is built through S-O-V. In general, the valence of verbs of all languages can be described in the form of existence and their compounding with verbs that are animate or bound to them, and this is called a universal compound of all world languages.

The valence of verbs in this study is the valence of Mandailing language verbs, as in the examples:

$\begin{array}{llllll}\text { 1a. Ia } & \text { manabusi } & \text { kareta } & \text { disi } & \text { Fiza } & \\ \text { He } & \text { boughta } & \text { bike } & \text { to } & \text { Fiza } & \\ \text { Third Person Sing V } & \text { VLS } & \text { PRE } & \text { VLS } & \\ \text { VLS } & & & & \\ \text { 1b. Ia } & \text { manabusi } & \text { si } & \text { Fiza } & \text { kareta } \\ \text { He } & \text { bought } & \text { to } & \text { Fiza } & \text { a bike. } \\ \text { Third Person Sing } & \text { V } & \text { PRE } & \text { VLS } & \text { VLS } \\ \text { VLS } & & & & \end{array}$

Another example can be seen in the following clause

\begin{tabular}{|c|c|c|c|c|}
\hline 2a. Hana & mandokl & tkon & siluluton & tu au \\
\hline Hana & tells & me the & news of orbituary & \\
\hline $\begin{array}{l}\text { Third Person Sing } \\
\text { VLS }\end{array}$ & V & VLS & & PRE VLS \\
\hline $\begin{array}{r}\text { 2b. Hana } \\
\text { Hana }\end{array}$ & $\begin{array}{l}\text { mandokkon tu } \\
\text { told }\end{array}$ & $\begin{array}{l}a u \\
\text { me }\end{array}$ & $\begin{array}{l}\text { siluluton } i \\
\text { the orbituary news }\end{array}$ & \\
\hline $\begin{array}{c}\text { Third Person Sing } \\
\text { VLS }\end{array}$ & PRE & VLS & VLS & \\
\hline
\end{tabular}

In clauses (1a) and (1b), two grammatical structures have the same meaning. Where clause (1a), He as valence is called a grammatical subject, while the valence of Fiza and Bicycle as arguments is called a grammatical object, namely the direct object and the indirect object which are connected by a preposition (for). In clause (1b), valence is still a grammatical subject, while the valence of Fiza as and Bicycles are interchangeable, and at the same time, the preposition (to) is no longer needed. However, in Mandailing, it is necessary to add specific morphological markers, "si." which makes the sentence the transitivity (valence) of Mandailing verbs increases the same as in clauses (2.a) and (2b).

Valence is related to the change in the number of arguments for the verb as a predicate in a clause, which is the mechanism for changing the valence that affects the argument. A or SUBJ and P or OBJ a verb (Haspelmath, 2002, p. 218). Furthermore, valence is related to terms related to increasing the number of arguments, namely the use of and the terms associated with decreasing the number of arguments, namely passivation, activation, and intransitivity. Thus, it can be concluded that in a sentence, there is a verb which is the core of the sentence. To form a good sentence with a clear meaning, a verb must be related to valence, namely, the ability that a verb has to relate to a particular argument, which fulfills a particular semantic function in a sentence. In general, it can be said that the term valence in linguistics is referred to as the ability of verbs, which occupy the predicate element of a sentence, in binding arguments. Aisen in Hopper and Thompson, ed., (1982, p. 8) argued that valence is used to refer to the number of petty arguments in a clause at any level. Katamba (1993, p. 266) states that valence is an argument in a syntactic framework associated with verbs caused by grammatical functions. In this study, the authors discussed the mechanism for changing the valence of verbs in the Mandailing language, wherein the Mandailing language changes in the valence of verbs can occur both in the form of subtraction and addition of valence in or sentences.

\section{Method}

The researchers used the method in obtaining the research data using the field linguistic research method where the researcher involved the participation of language speakers directly with unique methods. As for this research, the required data are qualitative descriptive data in oral and written forms that have been collected. Djajasudarma (1993, p. 13) argues that research using the description method will go through exposure to the reality of language phenomena as they are both systematically, factually, and accurately and the properties and relationships of the phenomena being studied. Researchers in collecting data used field linguistic research methods and library methods (documentaries). The researcher used the particular method 
in analyzing the data because this method is a method of analysis that is part of the language being studied as a determining tool for analysis. In the technique of providing data, the researcher used a method called listening and proficient techniques. This research is included in descriptive-qualitative research (Sudaryanto 2015: 62; Sugiyono 2013:26). This research uses the observation method and interview method. The observation method is used to obtain data by listening to the use of spoken language by the informants. The interview method is in the form of conversations between researchers and informants in collecting research data. The data validity criteria, the researchers used several techniques to the data collection in this study such as derivatives of the methods used, namely the tapping technique, the skillful listening technique, the recording technique or note-taking technique, and the fishing technique. The descriptive method used in this study is directly related to data collection, data analysis, and presentation of research results. This descriptive method is intended to make systematic and accurate descriptions related to the data found in the field. This research is included in field research because this research data is from speakers or informants. The primary data of this study were recorded directly. Thus, the provision of data that researchers use in this study refers to grammatical typology, while in data analysis, the methods used are the equivalent method and the Agih method (Sudaryanto, 1993: 13-16). The equivalent method used is based on the language reference itself, especially in determining the predication and structure of the clause argument and the semantic role of verbs in the Mandailing language.

\section{Results and Discussion}

\subsection{Results}

Valence refers to the syntactic relationship between verbs and elements around them, includes transitivity and mastery of verbs over the arguments around them (Kridalaksana, 2008). Haspelmeth (2002) explains that valence is information about semantic rules and the syntactic function of a verb. He said syntactic valence (syntactic valence) is briefly called functional structure, and semantic valence (semantic valence) is called the argument structure. Valence can change according to the mechanism. According to him, the increase in valence (enriched, increase valence) can be causative and applicable (compare with Katamba, 1993: 270272). A decrease in the valence (enriched, increase valence) can be done through passive, anticipative, and resultative.

Further, he said that valence is related to transposition. Valence refers to the number of different element types associated with verbs. Valence is a term not only used in the field of linguistics.

This typology research focused on aspects. The language possessed by the Mandailing Language, namely syntactic and semantic aspects in the study of the syntactic field, includes three aspects, namely (1) phrases, (2) clauses, and (3) sentences. Therefore, this syntactic study focuses on the discussion of the structure of clauses and sentences in the Mandailing language, structure methods, valence patterns, and complex structure for the syntactic typology of the Mandailing Language based on its grammatical alliance system. where the Mandailing clause argument system includes the mechanism of changing valence in verbs, and this supports the study of typology.

The term valence refers to the number of noun arguments clause at whatever level people call it (Aissen in Hopper and Thompson, 1982: 8). Judging from the type, valence can be divided into two, namely semantic valence and syntactic valence. Semantic validation is valence related to the number of participants who must attend, which is expressed by a verb, while syntactic valence or valence grammatical is the valence associated with the number of actual arguments in specific clauses (Payne, 1977: 169-170). Katamba (1993: 266) argues that valence is the number of arguments in the framework syntax associated with verbs caused by grammatical functions.

Valence can be divided into two types, namely syntactic valence and semantic valence. Syntax validity is the sum of arguments required by verbs as predictors (such as SUBJ and OBJ), and semantic valence is the number of semantic arguments required by verbs as predicators (such as actor and undergoer). Furthermore, the term valence is an element related to verbs or abilities, a verb that can represent other constituents like a clause. Valence is also used to refer to the clause's nominal argument count. Syntactically, arguments from verbs can be SUBJ, OBJ, OBL, and in the semantic argument in the form of actor and undergoer called role general (macro rule) and their particular role / thematic roles (Dixon, 2010: 165). The two concepts of valence above have the same basic concept, namely relating semantic and syntactic problems. Grammatical structure and argument structure is a concept at the syntactic level. A structural argument is a syntactic level, and the valence change is an argument operation structure (Manning, 1994: 41). In linguistics, valence is described as a verb that occupies a predicate function in a sentence to bind arguments. Valence is also described as the number of participants bound to the verb and arguments that the verb can tie (Tesniere, 
1959: 238). Van Valin and LaPolla (1999: 147-150) also say that valence is the number of arguments taken by the verb. Therefore, valence can be divided into two, namely syntactic valence and semantic valence. Syntax validity refers to the number of tangible arguments the verb takes. Semantic validation refers to the number of participants who appear in the expression of a verb.

In this section, the researcher will discuss the subject, which includes the mechanism of changing the valence of Mandailing verbs, which focuses on verbal predicated clauses with clause construction or sentences predicated on intransitive verbs and transitive verbs. The valence change in the Mandailing language can be seen in the example clause mangan "eat" in umak mangan "mom etas" verb mangan "eat" has one argument syntactically and has two arguments semantically, namely who eats and what is eaten. Thus, the verb mangan "eat" in clause umak mangan jegang, "mom eats the corn," can be changing in valence. For example, in the clause jegang madung i pangan, "the corn was eaten," and syntactic valence changes from two arguments to one argument. In the Mandailing language, the mechanism of valence change in verbs include causative, applicable, and resultative constructs, the discussion of these constructs can cause changes in valence both syntactically and semantically. Artawa (1998: 32) states that one significant syntactic difference between non-causative constructs and causative constructs is the increase in the valence of verbs in the causative constructs. This research aimed to describe the change in valence in the Mandailing language with the type of verbs that then analyzed the data. Next, this research aims that the mechanism for changing the valence of the verb in Mandaialing can be seen whether it is based on the emphasis on the difference in the valence of the verb.

\begin{tabular}{|c|c|c|c|}
\hline Consider the followir & amples: & & \\
\hline 3. halai sude & ke he tu V & & \\
\hline They all & go to th & & \\
\hline Third person plu & & & \\
\hline 4. Ayah si mirna & maro & & \\
\hline Mirna's dad & is coming & & \\
\hline First person sing & & & \\
\hline 5. Karetti & marumbak & to & ulu aer \\
\hline The rubber tree & fell & into & the river \\
\hline First person sing & & & \\
\hline
\end{tabular}

Intransitive verbs $k e$ he 'go' when given a marker-ke be transitive verbs and same with the Intransitive verbs ma ro 'come' given marker-ma, Each of the clauses (3,4, and 5) verbs that have received these morphological markers change (increase) in their transitivity with the evidence that the three of them require a second argument, namely the object (grammatical). In other words, the valence of the intransitive verb increases with the change in its transitivity. Based on this fact, the transitivity (valence) of the Mandailing language verbs increases with specific morphological markers. Next, look at the clauses with the following Mandailing transitive verbs.

\begin{tabular}{|c|c|}
\hline 6. Ayah & Mangan \\
\hline Father & eats \\
\hline First-person sing & $\mathrm{V}$ \\
\hline VLS & INTRANS \\
\hline 7. $A u$ & mangalehen \\
\hline I & give \\
\hline First-person sing & $\mathrm{V}$ \\
\hline VLS & INTRANS \\
\hline
\end{tabular}

mangan 'eats' and mangalehen 'give' in clauses ( 6 and 7) as verbs with one valence cause these verbs only animate with one element, namely in the clause (6), ayah mangan 'Father eats' is a pronoun that serves as the subject of the clause. Although the clause can be extended to father eating very slowly, the father eats accompanied by the mother, the father eats in the restaurant, and so on, but the element is very devoured, accompanied by the mother and in the restaurant is not a valence of the verb of eating. The same is the case with my elements in the clause (7) au mangalehen 'I give,' where I is the element and as a pronoun that serves as the subject of the clause, and this clause can also be expanded into me giving to the mother, I give gifts to the sister, etcetera. Nevertheless, that does not mean that the phrases are positioned as the valence of feeding and feeding verbs. The phrase to gift, mother, car grammatically is only a complement or complement of the speech and not domiciled as the valence of the verb.

$$
\text { 8a. Ayah manabusi baju tu umak }
$$




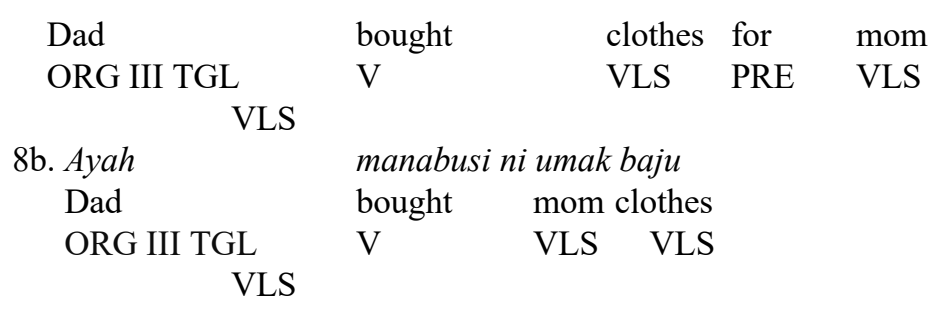

Clause (8a) and (8b) are two grammatical structures that contain the same meaning. In clause $8 a$ ), the father is the valence that serves as the clause's grammatical subject, while the mother's valence and clothes are arguments that function as grammatical objects, namely direct objects and indirect objects connected by a preposition (for). In clause (8b), the father's position in valence remains a grammatical subject, while the mother's valence and clothes occupy an interchangeable position, and at the same time, the preposition (to) is no longer needed.

There can also be a reduction in the valence in the valence change mechanism because one of the valences is omitted. After all, its presence in the clause is not very important or optional. The reduction in valence that occurs in passive sentences, both in the Mandailing language, is the same as in the Indonesian clause, as in the example below:

$\begin{array}{lll}\text { 9. Pangkur dibuat } & \text { ngon gudang } & \text { (sada halak) } \\ \text { The hoe was taken from the warehouse } & \text { (someone). } \\ \text { VLS V PASS PRE VLS } & \\ \text { 10. Kareta angin ditabusan natuari } & \\ \text { Bike was bought yesterday (Rafi). } & \\ \text { VLS V PASS VLS } & \\ \text { 11. Bubur dipamasak } & \text { (sister). } \\ \text { Porridge cooked } & \\ \text { VLS } \quad \text { V PASS } & \text { VLS }\end{array}$

The valence of "someone" in clause (9) and Rafi in clause (10) and sister in clause (11) are valences that function as an actor or agent. The three valences are neglected because their presence in the three clauses is not necessary. So that it is appearance is optional. By any other examples:

\begin{tabular}{|c|c|c|}
\hline 12a. Ia & manabusi & ngan tokoi \\
\hline $\mathrm{He}$ & buys & from the store. \\
\hline $\begin{array}{c}\text { Third person sing } \\
\text { VLS }\end{array}$ & V PASS & PRE \\
\hline $\begin{array}{l}\text { 12.b Umak } \\
\text { Mom }\end{array}$ & $\begin{array}{ll}\text { ma ro } & \text { sian } \\
\text { came } & \text { from }\end{array}$ & $\begin{array}{l}\text { kampung } \\
\text { the village }\end{array}$ \\
\hline Third person sing & V PASS PRE & VLS \\
\hline
\end{tabular}

Data in clauses (12.a and b) are clauses whose verbal construction uses the intransitive verb predicate. This clause has one core argument, which serves as a grammatical subject. In clause (12), ia 'He' and umak 'mom' are the argument of the predicate manabusi 'buys', which gets paraphrased, and ma ro 'came', which appears as a verb with morphological markers and without other elements that are part of the predicate. Predicates like this are known as simple predicates, which only have a single parent (simple head). Based on the data analysis above, the valence change in Mandailaing language can be examined as follows: a change in the valence of an intransitive verb requires one argument, for example:

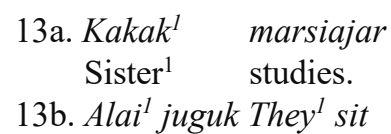

A transitive verb that takes two, for example:

14a. Ucok $k^{l}$ mambukkok bola
Ucok $(\mathrm{He})^{1}$ throws the boll ${ }^{2}$.
$\begin{array}{cl}\text { 14b. Umak } & \text { manyirom bunga } \\ \text { Mom }^{1} & \text { plants the flowers }\end{array}$

A transitive verb that takes three, in the example:

15a. Ho $^{1}$ mangalehen ${ }^{2}$ bunga isia ${ }^{3}$

$\mathrm{He}^{1}$ gives her $^{2} \quad$ flowers ${ }^{3}$ 
15b. $\mathrm{Ho}^{1}$ mangalehen ${ }^{2}$ kado isia ${ }^{3}$

You ${ }^{1}$ bring her $^{2}$ gift $^{3}$

Based on the sentences above, there are verbs as the core of the sentence. To form a good sentence and have a clear meaning, the verb must be related to valence, namely, the ability of verbs to relate to specific arguments, which fulfill certain semantic functions in a sentence (Appel, 1992: 136). In general, verbs have only one 'possible valence', the same thing in the Mandailing language. However, it turns out that several verbs can have more than one 'possible valence', which can have the possibility of being multiple or one of them. In this regard, this study aims to determine the types of Mandailing verbs that can experience changes in valence, symptoms, and processes of change and the semantic role of these verbs. From the analysis, it can be concluded that the change in valence mainly occurs in intransitive, transitive, and transitive verbs, which are grouped into symptoms that cause a decrease in valence and expansion of valence.

\section{Conclusion}

The Valence changes in the verb in Mandailing language suggest that this section focused only on the study of verb predicate Mandailing clauses mainly related to constructing clauses or sentences with intransitive verbs and transitive verbs. Verbs in Mandailing require all of their arguments in well-formed sentences, although they can sometimes experience reduction or expansion of valence. For example, the verb "eat" can be changed to two valences, in clause he eats apples, but can be reduced to one valence when he eats. This is called valence reduction, same within verb manabusi "buy," which in marker ma- can change from one valence to two valences in Mandailing language. Verbs that are usually one valence, such as sleep, cannot retrieve objects directly. However, there are cases where the valence of the verb can be expanded, for example, in he sleeps, the sleep of death. This is called valence expansion. The validity of the verb can also be described in terms of syntactic versus semantic criteria. Syntactic validity of a verb refers to the number and types of dependent arguments a verb has, whereas semantic valence describes the thematic relationships associated with a verb. Based on the results and discussion of analysis in this study, it can be concluded that the term valence change in linguistics is the ability of verbs, which occupy the predicate element of a sentence, in binding arguments. From the research and discussion results, the researcher concluded that the behavior of verbs, especially valence, is the essential element in a sentence. Verbs prepare empty spaces to be filled with a complement called valence to form a grammatical and meaningful sentence. To describe valence, such as determining the number of valences of the verb and subtracting the valence, the verb in these cases does not have a set of easily relevant verbs and can be defined in semantic terms. Thus it is difficult to generalize across classes of verbs on the change in valence in the Mandailing language.

In general, this research aims to explore, analyze, and explain the Manadailing language phenomenon as well as introduce the facts of the Mandailaing language related to changes in valence in the study typology. In this research that researchers have carried out theoretically, the studies that have been carried out are expected to be helpful in typological linguistic development. Applying the linguistic typology theory in analyzing the change in valence in the Mandailing language is expected to contribute to the description of the Mandailing language and be considered in the development, development, and assistance of regional language conservation. To do this research correctly, a means of thinking is needed. The availability of these tools allows for regular and careful scientific study. Without mastering this, good research cannot be carried out. Facilities and infrastructure are tools that assist activities in the various steps that researchers must take so that facilities in the form of informants, language, and supporting sources are needed to run well, orderly, and carefully.

\section{References}

A. Putu Suari, I Ketut Artawa \& Made Sri Satyawati. (2015.). Mekanisme Penaikan Valensi Bahasa Bali Dialek Nusa. Penida (BBDNP). E- Journal "Language and Translationn Studies", 1 (1)

Antonio Constantino Soares. (2016). Verba Bervalensi Satu, Dua, Dan Tiga Pada Bahasa Makasae. Jurnal Pesona. Volume 2 No. 1, 74-84

Asridayani. (2017). Analisis Kontruksi Verbal Dan Mekanisme Perubahan Valensi Verba Bahasa Batak Toba. Krinok: Jurnal Linguistik dan Budaya. 2 (2)

Budiarta, I Wayan. (2013). Tipologi Sintaksis Bahasa Kemak. (Disertasi). Denpasar: Universitas Udayana

Comrie, Bernard. 1989. Language Universal and Linguistic Typology (2nd Edition). Oxford: Basil Blackwell. 
Daniel, Michael, Zaira Khalilova \& Zarina Molochieva. (2010). Ditransitive constructions in East Caucasian: A family overview. In Andrej Malchukov, Martin Haspelmath \&Bernard Comrie (eds.), Studies in Ditransitive Constructions: A Comparative Handbook, 277-315. Berlin: De Gruyter Mouton.

Djadjasudarma. (1993). Metode Linguistik: Ancangan Metode Penelitian dan Kajian. Bandung: Eresco

Greenberg. JH (1963). Universal of Language. Massachusetts. The MIT Press.

Grimshaw, Jane A. (1990), Argument Structure. Cambridge/MA: MIT Press

Hopper, Paul J., dan S. A. Thompson, (1982). Syntax and Semantics: Studies in Transitivity. New York: Academic Press Inc.

Budiarta, I Wayan. (2013). Tipologi Sintaksis Bahasa Kemak (Disertasi). Denpasar: Program Pascasarjana Universitas Udayana.

Ida Basaria. 2011. Relasi Dan Peran Gramatikal Bahasa Pakpak Dairi: Kajian Tipologi. Disertasi. Sekolah Pascasarjanauniversitas Sumatera Utara

Jufrizal. (2007). Tipologi Gramatikal Bahasa Minangkabau: Tataran Morfosintaksis. Padang: UNP Press

Katamba, Francis. (1993). Morphology. London: The Macmillan Press.

Kridalaksana, Harimurti. (2000). Kelas Kata dalam Bahasa Indonesia. Jakarta: PT Gramedia Pustaka Utama

Paul, Peter. (1999). Linguistics for Language Learning and Introduction the Methodical Study of Language its Nature and its Uses. Medan: Program Pascasarjana USU

Purwanto Siwi. (2018). Sintaksis Bahasa Siladang: Kajian Tipologi Gramatikal. Disertasi. Program Doktor (S3) Linguistik Fakultas Ilmu Budaya Universitas Sumatera Utara

Sudaryanto. 1993. Metode dan Aneka Teknik Analisis Bahasa. Yogyakarta: Duta Wacana University Press

Tambusai (2016). Tipologi Morfologis dan Struktur Argumen Bahasa Melayu Riau. Disertasi. Universitas Sumatera Utara.

Verhaar, J, W, M. (1999). Asas-Asas Linguistik Umum. Yokyakarta: Gajah Mada University Press

Whaley, Lindsay, J. (1997), Introduction to Typology, the Unity and Diversity of Language. California: Sage Publications, INC

\section{Abbreviations List}

To facilitate the discussion of this study, several abbreviations are used as in the following table

\begin{tabular}{ll}
\hline Abbreviations & Form \\
\hline ORG Person & ORG Person \\
\hline TGL Singular & TGL Singular \\
\hline JMK Plural & JMK plural \\
\hline JMK Plural & JMK plural \\
\hline TRANS Transitif & TRANS Transitive \\
\hline INTRANS Intransitive & INTRANS Intransitive \\
\hline PRE Preposisi & PRE Preposition \\
\hline PASS Passive & PASS Passive \\
\hline VLS Valence & VLS Valence \\
\hline
\end{tabular}

